\title{
EMPIRICAL STUDY OF TWIN DEFICITS IN INDONESIA: THE RELATIONSHIP BETWEEN CAUSALITY AND EARLY WARNING SYSTEM OF TWIN DEFICITS' CAUSE
}

\author{
Prawudya Dery Kuncahyo*1 \\ ${ }^{1}$ Faculty of Economics and Business, Universitas Airlangga, Indonesia
}

\begin{abstract}
The aim of this research is to investigate the causality of deficit budget with the current account deficit (twin deficits) in Indonesia and to detect the decision indicators of twin deficit as an early warning system model of twin deficits' occurrence. The research applied a quantitative approach with granger causative data to find the significant relationship of twin deficits in Indonesia. At the early stage, it analyzes the detection of twin deficits by using quantitative phenomenological approach in a form of mathematic formula calculation via non-parametric model with EWS signal extraction. It used 1 derivation standard (DS) and 24 months signal windows to extract signal. Signal extraction is applied to monitor the evolution of economic indicators which has a systematic tendency of twin deficits in Indonesia. Microsoft Office Excel 2007 and E. Views 7 are the software used within this research. The result of this research signified that there is a relationship between twin deficits in Indonesia with the budget deficit which is influencing the current account deficit. It strengthens the Twin Deficits Hypothesis (TDH) that explains the existence of budget deficit will affect the current account deficit by access of interest rate. Additionally, the result of a signal extraction calculation from the chosen indicator variable trend showed a positive signal of twin deficits. It is justified by the abnormal behavior of variables which states up to 50 percent probability. Those variables are export growth, import growth, terms of trade, inflation, growing industrial sector, real exchange rate, foreign reserve growth, and growth of world oil price.
\end{abstract}

Keywords: Budget deficit, Current Account Deficit, Early Warning System.

JEL: F32, F41

\section{ARTICLE INFO}

Received: April 21 ${ }^{\text {th }}, 2016$

Revised: May 10 ${ }^{\text {th }}, 2016$

Accepted: May $19^{\text {th }}, 2016$

Online: June $27^{\text {th }}, 2016$

\author{
*Correspondence: Prawudya Dery \\ Kuncahyo \\ E-mail: \\ prawudya.dery@gmail.com
}

To cite this document: Kuncahyo, P.D. (2016). Empirical Study of Twin Deficits In Indonesia: The Relationship Between Causality and Early Warning System of Twin Deficits' Cause. JDE (Journal of Developing Economies), 1(1), 63-75

\section{Introduction}

Twin-Deficit in Indonesia was seriously attended in the beginning 2013. Its discourse appeared in the middle 2012 when trade balance experienced pressure in several months (April-May-June 2012). Concurrently, the fiscal condition beaten by deficit pressure causing the decreasing ability to inject the net-export and investment. Therefore, it made the deficit of the current transaction balance.

In 2012, Indonesia's deficit fiscal grew up to IDR 190.1 billion or $2.23 \%$ of PDB (it was still secure under $3 \%$ ). It was contributed by primary balance of deficit through IDR 45.5 billion, the first since 2009 in which it was surplus IDR 5.2 billion. In 2013, fiscal deficit in APBN

JDE (Journal of Developing Economies) p-ISSN: 2541-1012; e-ISSN: 2528-2018 DOI: http://dx.doi.org/10.20473/jde.v1i1.1786

Open access under a Creative Commons Attribution 4.0 International

(CC-BY) 
was targeted $1.65 \%$ of PDB and primary balance of deficit was in IDR 36.9 billion. Nevertheless, the comparative balance got deficit of USS 1.6 billion in 2012. It was also the first time event ever since 2009 which acquired surplus USS 19.6 billion then surplus USS 22.1 billion in 2010 and surplus USS 26 in 2011.

The twin deficit was worrying because it would decelerate national development and suppress the current process of development. This phenomenon was similar with USA and other countries which was oppressed by crisis in last years (2008/2009). Global uncertainty and recession after crisis of Europe, U.S and increasing escalation at UEA, North - South Korea, Japan - China have affected at decreasing global demand, and as significant included demand to Indonesia.

Previous studies express that twin deficits (fiscal deficit and current transaction deficit) in a certain country can relate to each other. The existence of twin deficits relationship can be explained as phenomenological event by twin deficit hypothesis (TDH). According to the theory, if fiscal policy faces expansion (fiscal deficit exists), the degree of interest rate will increase. The Increasing of interest rate affects capital inflows to stimulate the real domestic exchange rate. It will be appreciated causing the decrease of the commerce competitiveness (caused by domestic product price which is more expensive in international market) and exacerbate the current account deficit (Salvatore, 2006).

Hence, the aim of this research is to analyze twin deficits relationship in Indonesia. Hypothesis of this study is suitable with twin deficits hypothesis and has relationship with budget deficit and current account deficit (Twin Deficit Hypothesis, TDH). Besides, this research will also investigate the economic fundamental behavior to analyze the indicator of the twin deficits' occurrences in Indonesia.

\section{Literature Review}

\section{Relationship of Twin Deficits Concept}

A relationship between current account deficit and budget deficit can be directed from the equation of national income as below:

$$
Y=C+I+G+(X-M)
$$

Description:

$Y \quad=$ National Income

$C \quad=$ Consumption

$I \quad=$ Private Investment

$G \quad=$ Government Expend

$X \quad=$ Export

$M \quad=$ Import

Besides, another equation that formulates national income is as such below:

$$
Y=C+S+T
$$

Description:

$Y \quad=$ National Income

$C \quad=$ Consumption

$\mathrm{S} \quad=$ Private Domestic Saving

$\mathrm{T} \quad=$ Tax 
Equation between (1) and (2) can be rearranged as:

$$
\begin{gathered}
C+I+G+(X-M)=C+S+T \\
X-M=C+S+T-C-I-G \\
X-M=S+T-I-G \\
X-M=(S-I)+(T-G)
\end{gathered}
$$

This Equation (6) is often mentioned as twin deficits relationship. It expresses deficit that occurs at current account $(X<M)$ and following by government budget deficit $(T<G)$. This twin deficits relationship is valid if only the gap between private sectoral investment and saving $(S-I)$ are assumed as constant (Hossain and Chowdhury, 2001).

According to theory, there are four possibilities between budget deficit relationship with current account deficit such as, one-way relationship from budget deficit to current deficit, current account deficit to budget deficit, two ways relationship at the both deficits, and independent/unrelated.

\section{Budget deficit affects Current Account Deficit}

Both relationships here are underlined by a big economy theory at twin deficits hypothesis. Conventional hypothesis concerning twin deficits relationship can be explained by two basic theories. The first, based on Keynesian Absorption theory, expresses that increasing budget deficit presses the increasing demand aggregate and national income that affects increasing import and exacerbates current account. The second, according to Mundell Fleming Framework (1963), mentions that increasing government budget deficit affects decreasing national saving that presses increasing degree of domestic interest rate and collective capital inflows. Increasing capital inflows influences the domestic currency demand increases and pushes appreciation. Domestic currency appreciation then stimulates the increasing import and decreasing export, so that the current account deteriorates (Bagheri \& Keshtkaran, 2012).

Mundell-Fleming model involves the different effect of government fiscal expansion based on exchange rate system applied in the economy of a country with mobility assumption modal that has perfect character. In fixed exchange rate system, expansive fiscal policy, the government moves IS curve to the right and increase interest rate then pulls capital inflows. Increasing of capital inflows increases a demand to domestic currency and affects appreciation of exchange rate. To return exchange rate to the appointed position by central bank, It must add the total of circulated exchange rate. Adding the total of circulated currency will move LM curve to the right and return domestic degree rate and exchange rate in its original position. Besides, the national income will increase from $Y_{1}$ to $Y_{2}$.

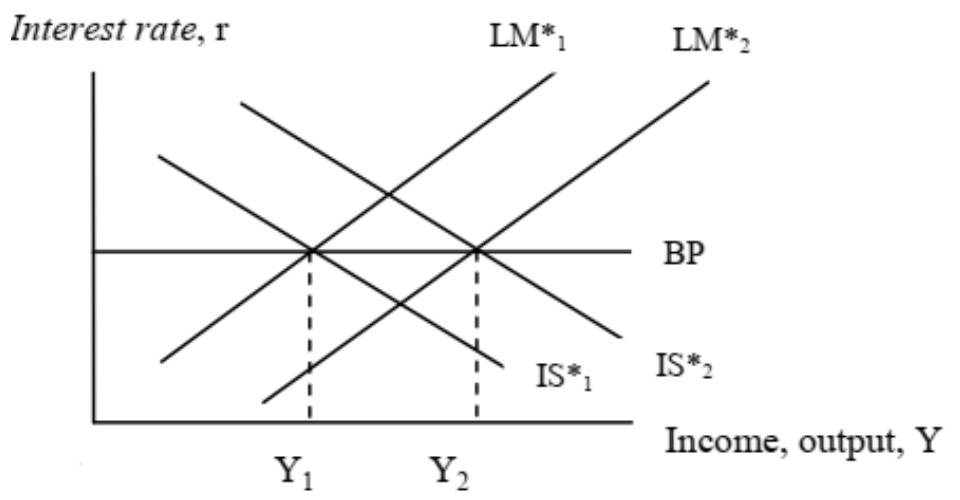

Figure 1: Fiscal Expansion Effect by National Income at Fixed Exchange Rate System 
Although exchange rate is back to the original position, increasing national income still pushes the ascending aggregate demand and import in short period. Whereas in the long one, the appreciation of real domestic currency will decrease export competitiveness and increases import that exacerbates the current account (Vyshnyak, 2000).

It will be different at regime of constant exchange rate. The fiscal expansion done by government in floating exchange rate cannot affect national income. Government fiscal expansion moves IS curve to the right and pushes increasing domestic degree rate and pulls capital inflows subsequently.

By constant total of circulated money, increasing capital inflows pushes an appreciation of domestic exchange rate that affects expensive domestic product in abroad and decreasing export. Meanwhile, import demand will increase and impulse the current account exacerbated. At once, it returns IS and $\mathrm{Y}$ curve to the original position.

\section{Interest rate, $\mathrm{r}$}



Source: Gartner (1993) and Vyshnyak (2000)

\section{Figure 2: Fiscal expansion effect about National Income in float exchange rate system}

The result of the research indicates support for Vyshnyak theory (2000) that found twin deficits relationship at budget deficit and current account deficit in Ukraine, Salvatore (2006) at G-7 country member, Bartolini and Lahiri (2006) at OECD countries and U.S, and Hakro (2009) that found that budget deficit affected current account in Pakistan by inflation variable, degree rate, and exchange rate. Besides, Bagheri \& Keshtkaran (2012) also found the similar relationship in Iran economy.

\section{Current Account Deficit Causes Budget Deficit}

This relationship occurred in the country which is depending on its international trade or doing market expansion so that the government felt balance of trade is very important and required much budget from the government to overwhelm the current account deficit affecting the country (Chang and Hsu, 2009). One-way relationship from the current account deficit to budget deficit contrast with twin deficit assumption. This phenomenon is recognized as Reserve Causation. The position of current account which is always worse can delay the economic growth and drop the level of national income because it can reduce foreign exchange reserve or even increase a debt which will burden the government budget and trigger the occurrence of budget deficit (Kalou dan Palaelogou, 2012). Based on Anoruo and Ramchander (1998), Chang and Hsu (2009), this relationship usually occurs in a developing country which applying market expansion and managing to overcome the problem of trade imbalance, especially if it can be expected threatening the domestic manufacturing industry and overseas market share, by increasing the costs from the government. 
The research implies the identical result with the previous explanation such as, Ardiyanto's research (2006) used the VAR method in Indonesia 1981-2004, Corsetti and Muller (2006) in USA, Canada, Australia, and England, Bose and Jha (2011) in India's economic, and Kalou and Palaelogou (2012) in Greece.

\section{Unrelated Budget Deficit and Current Account Deficit (Independent)}

Based on the equation (6), the relationship between budget government and current account can be formulated as $X-M=(S-I)+(T-G)$. The twin deficits relationship does not occur if the government decides the expansive fiscal policy like tax cuts $(T)$. Thus, the government budget deficit can be increased. Yet, the increase of budget deficit does not influence in rate degree, exchange rate and current account, it does not cause the current account deficit simultaneously (Barro, 1989).

The twin deficits relationship (independent/unrelated) is clarified in Ricardian Equivalence Hypothesis (REH) approach. Using the assumption that a perfect information and society can think rationally, they realize that the increase of budget deficit government as impact of tax cuts at the time. It will encourage the government to increase the tax $(T)$ in the future to pay the debt. The society then will save more income $(S)$ to anticipate the increase tax in the future. Finally, the national savings is down because the saving of the government is depressed. It will be covered with the increase private saving (society) with the same number. Therefore, it also indicates that twin deficits will not occur in a country which has high saving rate.

The twin deficits phenomenon will not happen if the fiscal institution in a country maintenance in responding every surplus/ fiscal deficit and mark the policy as the condition. The unresponsive fiscal policy will cause interest rate and it will affect in exchange rate. It always causes deficit in balance of trade (Artana et.al, 2003). According to Corsetti and Müller (2006), a country will be easier to predict twin deficits if the country has a higher degree of openness and consistently practice the expansive fiscal policy without adapting the economic condition.

The relationship is reinforced by Ganchev's research (2010) in Bulgaria's case. It is caused due to the fact that the country has the fiscal surplus policy by the government and used it to reduce current account deficit and to pay the debts of the country.

\section{Bidirectional between Current Account Deficit and Budget Deficit}

The last relationship is two-way relationship between current account deficit and budget deficit which means the current account deficit can cause budget deficit and in vice versa based on the research of Feldstein and Horioka (1980). They found a strong correlation with domestic investment. In fact, under the perfect assumption of capital mobility, the domestic investment can be guaranteed by foreign saving.

According to Baharumshah and Lau (2009), if the government budget deficit in economic based on the fixed exchange rate that is guaranteed with too large international market, the monetary expansion affects the unbalance of the currency market and results to the degraded current account. However, if the export price increase because of the increase of weld demand, the current account balance will be better and encourage the increase of the government revenue from export reception and the budget deficit will be depressed.

The relationship is covered by the research of Baharumshah et al. (2009) in Thailand. 
They used budget balance data and current account balance. It is also supported by Baharumshah and Lau (2009) research in Malaysia. Atlintas and Taban (2011) also found two-way debits, where one of the sides in budget deficit affecting current account deficit, and the other current account affecting budget deficit in investment variable.

\section{Early Warning System in Twin Deficits}

Generally, the EWS (Early Warning System) model with signal approach can be used as a detector of financial crisis in a country. The research of Early Warning System before the occurrence of the exchange rate crisis using the signal approach is developed by Kaminsky et al. (1998). It used non-parametric model known as KLR model with signal extraction. It is used to monitor the evolution of economic and financial indicator. This model can predict the possibility of the event of financial crisis within the specified time period, in this case Kaminsky used signal windows 24 months.

This research will refer to concept produced by Kaminsky. It uses the EWS model with signal approach as the detector twin deficits in Indonesia due to its large and persistent characters. It can disrupt the sustainability of macroeconomic in a country and expected as the cause of financial crisis in country as happened in European and Asia debt crisis 1997/1998 (Anoruo and Ramchander, 1998).

Indicator variables used to detect twin deficit are taken from indicator variables which are used as the detection of financial crisis. Some of the researches who are using the indicators are Kaminsky et al (1998) in Handoyo (2006).

\section{Research Method and Models}

To analyze a relationship of twin deficits (budget deficit and current account deficit) in Indonesia research object, the period used is between 1981 till 2012. Model specification in this research using Causative Granger method as below:

$$
\begin{aligned}
& B D=\sum_{j=1}^{n} \beta_{1 j} B D_{t^{-j}}+\sum_{j=1}^{n} \beta_{2 j} C A D_{t^{-j}}+\varepsilon_{t} \\
& C A D=\sum_{j=1}^{n} \gamma_{1 j} B D_{t-j}+\sum_{j=1}^{n} \gamma_{2 j} C A D_{t-j}+\varepsilon_{t}
\end{aligned}
$$

Description:

$$
\begin{array}{ll}
B D & =\text { Budget Deficit } \\
C A D & =\text { Current Account Deficit } \\
\varepsilon_{t} & =\text { Error Term }
\end{array}
$$

Likewise, the research about early detection of twin deficits is completed by using nonparametric model with rapprochement extraction signal EWS, using 1 derivation standard (DS) and 24 months signal windows to extract signal. That signal extraction is used to monitor indicator economy evolution that has a systematic tendency about the occurrence of twin deficits in Indonesia.

Chosen leading indicator is relied on a rational principle of economy of a behavior happened several months before the twin deficits event. In this research, chosen indicator is a development of Kaminsky's research and etcetera (1998) in Handoyo (2006), particularly in the relationship about currency crises and debt crises. The used variables are real exchange rate, import growth, export growth, terms of trade, industrial production index, foreign reserve growth, inflation, and world oil price. 


\section{Result and Discussion Analysis of Relationship Twin Deficits}

To analyze twin deficits research using Granger non-causality method, it applies electrometrical tools EVIEWS 7. Analysis of Granger non-causality result in this research is showed in this table.

Table 1: The Result of Bivariate Granger Causality

\begin{tabular}{lll}
\hline Null Hypothesis: & F-Statistic & Prob. \\
\hline BD does not Granger Cause CAD & 3.43940 & $\mathbf{0 . 0 3 3 6 *}$ \\
\hline CAD does not Granger Cause BD & 1.43606 & 0.258 \\
\hline
\end{tabular}

From the Bivariate Granger non-Causality testing result, hypothesis shows that $\mathrm{Ho}$ express $B D$ does not influence $C A D$, and $C A D$ does not influence $B C$. By pointing a probability value as big as 0.0336 , Ho is prevented. It means that $\mathrm{BD}$ influences CAD. On the other hand, the second statement has probability value as big as 0.2580 and at $a=5 \%$, consequently Ho is received with the result that CAD does not influence BD. From the Granger testing above, it can be concluded that twin deficits happened in Indonesia involves the relationship between budget deficit and current account deficit.

\section{Analysis of early twin deficits detection}

This research used signaling windows 24 months. It means that in 24 months, the variable indicator will give a signal first before twin deficits occurred. Detection process of twin deficits ensues at a variable which passes a normal limit (threshold). Twin deficits signal (1) will appear when $X_{t-j}$ passes limited certainty and no twin deficits signal $(0)$ when $X_{t-j}$ does not pass its limit threshold.

Every mentioned variable has a different relationship between each other. Some variables have positive relationship with twin deficits such as import growth. The increasing import can be the early warning of twin deficits. Meanwhile, there are some variables that have negative relationship with twin deficits such as export growth. The decreasing export indicates omitting competitiveness of domestic commodity in international capital market. This situation becomes early warning of a soon-to-be twin deficits event.

Table 2: Position When Passing Threshold

\begin{tabular}{lll}
\hline \multicolumn{1}{c}{ Indicator Variable } & Threshold Position \\
\hline 1. & Real Exchange Rate & Above \\
\hline 2. & Impor Growth & Above \\
\hline 3. & Export Growth & Below \\
\hline 4. & Terms of Trade & Below \\
\hline 5. & Industrial Production Index & Below \\
\hline 6. & Foreign Reserve Growth & Below \\
\hline 7. & Inflation & Above \\
\hline 8. & World Oil Price & Above \\
\hline
\end{tabular}

From this definition, an indicator can be measured. If the indicator demonstrates a signal that is directed to a possibility of twin deficits condition, It can be declared as a good signal. But if the signal is not directed to a condition of twin deficits for 24 months later, It can be classified as fake signal or false signal. 
The observations at each indicator can be categorized in four possibilities as below:

Table 3: Signal Matrix of Twin Deficits

\begin{tabular}{lcc}
\hline & $\begin{array}{c}\text { Happening twin deficits in period of 24 } \\
\text { months later }\end{array}$ & $\begin{array}{c}\text { Not happening twin deficits in } \\
\text { period of 24 months later }\end{array}$ \\
\hline Exist signal & A & B \\
\hline No signal & C & D \\
\hline Source: Lestano, Jan Jacobs, and Kuper in Handoyo (2006)
\end{tabular}

Matrix above displays signal classification to be 4 categories such as, A, B, C, and D. Hence, the table below illustrates a total result and indicator behavior in Indonesia.

Table 4: Signal Total in Indonesia

\begin{tabular}{clllll}
\hline & Signal Total Variable & A & B & C & D \\
\hline 1 & Real Exchange Rate & 6 & 4 & 22 & 40 \\
\hline 2 & Export Growth & 9 & 2 & 24 & 37 \\
\hline 3 & Import Growth & 5 & 4 & 25 & 38 \\
\hline 4 & Terms of Trade & 10 & 2 & 17 & 43 \\
\hline 5 & Foreign Reserves Growth & 8 & 2 & 21 & 41 \\
\hline 6 & Inflation & 5 & 5 & 23 & 39 \\
\hline 7 & Ratio of Industrial Production & 5 & 2 & 25 & 40 \\
\hline 8 & World of Oil Price & 9 & 5 & 22 & 36 \\
\hline Source: Author's calculation & & & &
\end{tabular}
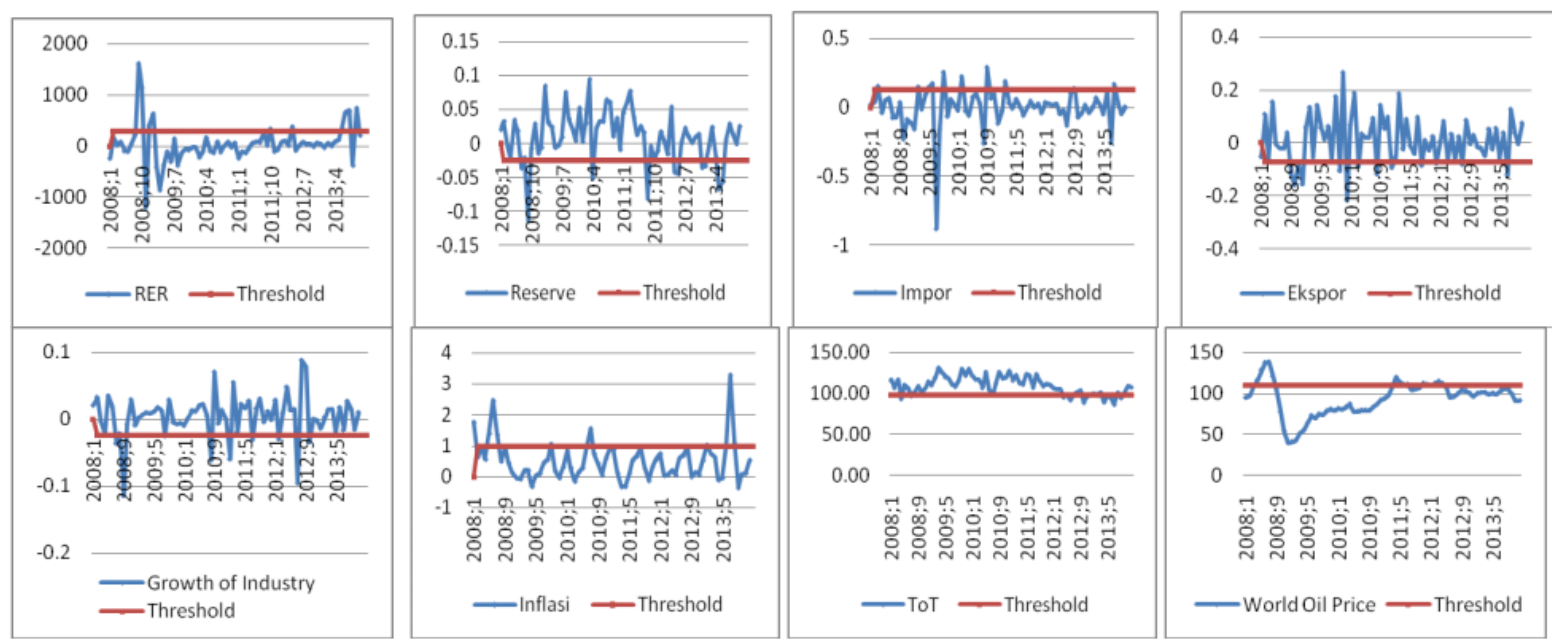

Source: Author's calculation

\section{Figure 3: Indicators and Threshold movement}

After identifying an indicator activity from each variable at table 4.5 above, the next phase, is also the last phase, is to appoint leading indicators that can be prepared. In this phase, the process is calculating the value of noise to signal ratio (NSR) and probability of twin deficits (PDT). NSR is used to measure total false signal by true signal in order to create NSR value that is the smaller to have the better result. If NSR value is same as one, it indicates that false signal is as good as true signal. Whereas, PTD is used to measure a probability of twin deficits after the signal is taken out by an indicator. The bigger PTD value, the better maximum value of $100 \%$. In this research, appointing leading indicators is emphasized more at a measurement of NSR and PTD value until each chosen indicator have NSR value smaller or similar as one and PTD value must higher than $50 \%$. 
Table 5: Noise to Signal Ratio and Probability of Twin Deficits in Indonesia

\begin{tabular}{|c|c|c|c|c|c|c|c|c|}
\hline \multirow{2}{*}{ Indicator } & \multirow[t]{2}{*}{ A } & \multirow[t]{2}{*}{ B } & \multirow[t]{2}{*}{ C } & \multirow[t]{2}{*}{ D } & \multirow{2}{*}{$A / A+C$} & \multirow{2}{*}{$B / B+D$} & NSR & \multirow{2}{*}{$\begin{array}{l}\text { Probability of } \\
\text { Twin Deficits } \\
\text { PTD=A/A+B }\end{array}$} \\
\hline & & & & & & & $(B / B+D) /(A /+C)$ & \\
\hline REER* & 6 & 4 & 22 & 40 & 0.214 & 0.091 & 0.424 & $60 \%$ \\
\hline Export Growth* & 9 & 2 & 24 & 37 & 0.273 & 0.051 & 0.188 & $82 \%$ \\
\hline Import Growth* & 5 & 4 & 25 & 38 & 0.167 & 0.095 & 0.571 & $56 \%$ \\
\hline Terms Of Trade* & 10 & 2 & 17 & 43 & 0.370 & 0.044 & 0.12 & $83 \%$ \\
\hline $\begin{array}{l}\text { Foreign Reserves } \\
\text { Growth* }\end{array}$ & 8 & 2 & 21 & 41 & 0.276 & 0.046 & 0.168 & $80 \%$ \\
\hline Inflation* & 5 & 5 & 23 & 39 & 0.179 & 0.114 & 0.636 & $50 \%$ \\
\hline $\begin{array}{l}\text { Industrial Production } \\
\text { Index* }\end{array}$ & 5 & 2 & 25 & 40 & 0.167 & 0,047 & 0,285 & $71 \%$ \\
\hline $\begin{array}{l}\text { Growth Of World Oil } \\
\text { Price* }\end{array}$ & 9 & 5 & 22 & 36 & 0.290 & 0.122 & 0.420 & $64 \%$ \\
\hline
\end{tabular}

Note: *: Indicator that has probability $>50 \%$ and NSR $<1$

From the table above, it can be inferred that eight macro economy variables have an appropriate requirement to be categorized as leading indicators. These eight variables are real exchange rate, Import growth, export growth, terms of trade, foreign reserves growth, inflation, industrial production index, and growth of world oil price.

\section{Discussion}

Based on a result of Granger causality test, twin deficits relationship in Indonesia has a relationship with budget deficit that influences current account deficit. This phenomenon is identical with twin deficits hypothesis. It describes that budget deficit of government will cause increasing rate of interest that will implicate in capital inflows and appreciate a domestic interest rate. Here, because of the competitiveness of domestic product depressed and yield a current account deficit, the result of this research is suitable with result of Vyshnyak's research (2000) to Ukraine case, Salvatore (2006) to member country case of G7, and Bagheri \& Keshtkaran (2012) to Iran case.

Besides, the result of signal extraction calculating from chosen variable indicator trend can perform a good signal to twin deficits. This phenomenon can be viewed from abnormal behaviour for each variable that shows NSR value less or same as 1 and probability value up to $50 \%$, its variables are Real Exchange Rate with value of noise to signal ratio (NSR) is as big as 0.42 and probability value of twin deficits is as big as $60 \%$, import growth with value of noise to signal ratio is as big as 0.57 and probability value of twin deficits is as big as $56 \%$, export growth with value of noise to signal ratio is as big as 0.19 and probability value of twin deficits is as big as $82 \%$, Terms of trade with value of noise to signal ratio is as big as 0.12 and probability value of twin deficits is as big as $83 \%$, Spare foreign exchange with value of noise to signal ratio is as big as 0.16 and probability value of twin deficits is as big as $80 \%$, inflation with value of noise to signal ratio is as big as 0.64 and probability value of twin deficits is as big as $50 \%$, Industrial sector growth with value of noise to signal ratio is as big as 0.28 and probability value of twin deficits is as big as $71 \%$ and Growth of World Oil Price with value of noise to signal ratio ia as big as 0.42 and probability value of twin deficits is as big as $64 \%$.

There are some leading indicator variables that have a big enough relationship as early warning of twin deficits in Indonesia such as, industrial production index with probability value of twin deficits is as big as $71 \%$ and has negative relationship about happened twin defi- 
cits. Therefore, its decreasing performed at industrial sector signifies the more probability of Indonesia to experience twin deficits. It is suitable with the important merit of output growth at industrial sector into national income. The high output industrial sector will result into increased export degree and strengthen balance position of current account. Additionally, It can fulfill domestic and national need. It can minimize the current account deficit opportunity, or on the contrary if there is a decreasing industrial output sector.

Also, another variable like terms of trade and export growth have value of twin deficits probability, each of it is as big as $83 \%$ and $82 \%$ and have negative relationship with twin deficits. It means decreasing export indicates ommiting competitiveness of domestic commodity in international market and this condition becomes significant early warning of twin deficits in Indonesia.

The decreasing of Indonesian balance of trade activity, which is always surplus all this time since crisis 1997/1998, became negative in 2012. It could not save the deficit balance of service and balance of income which its gap is widening and affect the deficit the current Indonesian account balance. The depressed of this commerce is especially affected by the lower of demand and the fallen of superior export commodity prices of Indonesia due to the global crisis factor in 2008.

Crisis in Europe in 2008/2009 affects the decreasing economy growth in the world included Asia such as Japan, China, India. It was proved in China manufacture industrial index since 2011 that tend to fall and on August 2011 had entered contractive phase as showed by purchasing managers Index rate which is at a level below 50 that period (contractive level) (Bank Indonesia, 2013). On the other hand, a high of domestic demand (consumption or investment) affected import volume of Indonesia in a high position. It caused Indonesia to face deficit in trade balance.

Indicator variable that also has a big relationship to become early warning of twin deficits in Indonesia is growth of world oil price as such with probability value of twin deficits (TDH) is as big as $64 \%$ and has positive relationship. It means that the running increase of the world oil price will be significant signal and affects twin deficits in Indonesia. It produces high national import value for covering domestic need which increases and affects a realization of higher oil consumption volume. This condition will potentially add the trade deficit at the current account and implicates a large oil subsidy in national estimate which is adding Indonesia budget deficit.

Finally, real exchange rate variable and foreign reserve growth have probability of twin deficits value each of as big as $60 \%$ and $80 \%$. This fact indicates a chosen indicator can also give a good signal as early warning of twin deficits in Indonesia. In the middle of uncertain domestic economy caused by global finance crisis in 2008, the policy synergy between government and Indonesia bank is very important to manage fiscal and monetary policy.

In general, Indonesia rate of interest growth so far is often higher than GDP growth. This rate of interest growth is far inferior than GDP growth. This condition signifies the central bank effort as monetary authority. It can respond fiscal alteration because there is still less synchronization between fiscal and monetary policy in Indonesia (Sriyana, 2005). There is a period that monetary authority can prevent a fiscal alteration. But in another condition, it cannot provide a significant effect about domestic of interest rate. Thus, it will influence the discouraging of exchange rate condition and/or state's stock exchange which means the higher potential of Indonesia to face twin deficits. 


\section{Conclusion and Recommendation Conclusion}

Based on result of granger causality test, there is a relationship of twin deficits in Indonesia with the relationship direction of budget deficit that influences current account deficit. It is similar with Twin Deficits Hypothesis (TDH) that expresses budget deficit will affect current account deficit by access of interest rate effect and exchange rate. Prevailing of twin deficits hypothesis suggests implication policy of effort for decreasing current account deficit which will need adjustment of the government fiscal policy and the anticipation of dynamics economy in the future. Hence, decreasing budget deficit becomes a requirement of erasing current account deficit effort.

A signal result calculation from variable chosen indicator of variable trend can give a positive signal of twin deficits prediction. It can be referred from some indicators which have NSR value less and/or equal to one and show probability of to-be-happening twin deficits up to $50 \%$. Those variables are export growth, import growth, terms of trade, inflation, industrial production index, real exchange rate, foreign reserve growth, and growth of world oil price.

\section{Recommendation}

According to the conclusion of Granger causality test, the relationship between twin deficits happened in Indonesia with the direction of relationship budget deficit that influence current account deficit shows that restraining current account deficit can be done by restraining budget deficit and anticipate the dynamics of economy in the future. Therefore, the government should prepare steps that can produce potential to press budget deficit and not to be implication of adding current account deficit. The concrete step that must be done such as, pressing national oil import because It can serve potential of adding commerce balance commodity and current transaction and calculate at quantity of oil subsidy in national estimate which is able to add more budget deficit. That effort refers to extraction signal result at indicator variable like Import Growth and Growth of World Oil Price.

Based on calculation result of term of trade indicator signal extraction and export growth, It indicates that the decreasing activity of Indonesia commerce is especially affected by low of demand and fallen prices of Indonesia superior export commodity caused by global crisis factor in 2008. Thus, it is required to do several things to verificate commerce in increasing export activity and building Indonesia competitiveness, reactivate Indonesia competitiveness as the way to expand a commerce partner of destination country or export commodity. This activity is done in order to make Indonesia export not only depend on any commodity and price fluctuation of world commodity.

In the uncertain condition of domestic economy caused by the global financial crisis, the synergy between government and Indonesian central bank is very significant to manage fiscal and monetary policy. These efforts will be influential for balancing the condition of IDR exchange rate and state's stock exchange. If it is done optimally, it will avoid the potential of twin deficits in Indonesian economy in the future.

\section{References}

Altintas, H., \& Taban, S. (2011). Twin deficit problem and Feldstein-Horioka hypothesis in Turkey: ARDL bound testing approach and investigation of causality. International Research Journal of Finance and Economics, 74, 30-45. 
Anoruo, E., \& Ramchander, S. (1998). Current account and fiscal deficits: Evidence from five developing economies of Asia. Journal of Asian Economics, 9(3), 487-501.

Ardiyanto, F. (2006). Analysis of Current Account Deficits and Fiscal Deficits in Indonesia: A VAR Approach. Jurnal Keuangan Publik, 4(2), 1-18.

Artana, D., Murphy, R. L., \& Navajas, F. (2003). A fiscal policy agenda. After the Washington Consensus: Restarting Growth and Reform in Latin America.

Bagheri, F., \& Keshtkaran, S. (2012). Testing for twin deficits and Ricardian equivalence hypotheses: Evidence from Iran. Journal of Social and Development Sciences, 3(3), 77-84.

Baharumshah, A. Z., Ismail, H., \& Lau, E. (2009). Twin deficits hypothesis and capital mobility: The ASEAN-5 perspective. Jurnal Pengurusan (UKM Journal of Management), 29.

Baharumshah, A. Z., \& Lau, E. (2009). Structural breaks and the twin deficits hypothesis: Evidence from East Asian countries. Economics Bulletin, 29(4), 2517-2524.

Barro, R. J. (1989). The Ricardian approach to budget deficits. Journal of Economic Perspectives, 3(2), 37-54.

Bartolini, L., \& Lahiri, A. (2006). Twin Deficits, Twenty Years Later. Federal Reserve Bank of New York Current Issues in Economics and Finance, 12(7).

Bose, S., \& Jha, S. (2011). India's twin deficits: Some fresh empirical evidence. ICRA Bulletin, Money and Finance, 1, 83-104.

Chang, J.-C., \& Hsu, Z. (2009). Causality relationships between the twin deficits in the regional economy. Department of Economics, National Chi Nan University, 04/06.

Corsetti, G., \& Müller, G. J. (2006). Twin deficits: squaring theory, evidence and common sense. Economic Policy, 21(48), 598-638.

Feldstein, M., \& Horioka, C. (1980). Domestic saving and international capital flows. Economic Journal, 90(358). https://doi.org/10.2307/2231790

Gärtner, M. (1993). Macroeconomics under flexible exchange rates. Harvester.

Ganchev, G. T. (2010). The twin deficit hypothesis: the case of Bulgaria. Financial theory and Practice, 34(4), 357-377.

Hakro, A. N. (2009). Twin deficits causality link-evidence from Pakistan. International Research Journal of Finance and Economics, 24(2), 54-70.

Handoyo, Rossanto Dwi. (2006). Early Warning System of Financial Crisis-Implementation of a Currency Crises Model for Indonesia. Majalah Ekonomi, Tahun XVI, no. 3. Desember, pp. 245-260.

Hossain, A. A., \& Chowdhury, A. (2001). Open-economy macroeconomics.

Bank Indonesia. (2013). Statistik Ekonomi dan Keuangan Indonesia (SEKI).

Kalou, S., \& Paleologou, S.-M. (2012). The twin deficits hypothesis: Revisiting an EMU country. Journal of Policy Modeling, 34(2), 230-241.

Kaminsky, G., Lizondo, S., \& Reinhart, C. M. (1998). Leading indicators of currency crises. Staff Papers, 45(1), 1-48. 
Mundell, R. A. (1963). Capital mobility and stabilization policy under fixed and flexible exchange rates. Canadian Journal of Economics and Political Science/Revue Canadienne de Economiques et Science Politique, 29(4), 475-485.

Salvatore, D. (2006). Twin deficits in the G-7 countries and global structural imbalances. Journal of Policy Modeling, 28(6), 701-712.

Sriyana, J. (2005). Ketahanan Fiskal: Studi Kasus Malaysia dan Indonesia. Economic Journal of Emerging Markets, 10(2).

Vyshnyak, O. (2000). Twin Deficit Hypothesis: The Case of Ukraine. Kyiv: National University Kyiv, Mohyla Academy. 